\title{
Ocena kosztów choroby
}

\author{
Aneta Mela ${ }^{1}$, Janusz Jaroszyński ${ }^{2}$ \\ ${ }^{1}$ Katedra i Zakład Farmakologii Doświadczalnej i Klinicznej, Centrum Badań Przedklinicznych i Technologii (CePT), \\ Warszawski Uniwersytet Medyczny, Warszawa \\ ${ }^{2}$ Katedra i Zakład Zdrowia Publicznego, Uniwersytet Medyczny w Lublinie, Lublin
}

Adres do korespondencji: Aneta Mela, Katedra i Zakład Farmakologii Doświadczalnej i Klinicznej, Centrum Badań Przedklinicznych i Technologii (CePT), Warszawski Uniwersytet Medyczny, ul. Banacha 1B, 02-097 Warszawa, e-mail: aneta.mela@gmail.com, aneta.mela@wum.edu.pl

\section{Wstęp}

Stały wzrost kosztów opieki zdrowotnej powoduje rosnące zainteresowanie problematyką oceny kosztów ochrony zdrowia, ich wplywu na gospodarkę, a także możliwościami ich ograniczenia. Towarzyszy temu rozwój badań nad ekonomicznym oraz społecznym obciążeniem chorobami i niesprawności. W poszukiwaniu sposobów redukcji kosztów opieki zdrowotnej niezbędna jest znajomość ich elementów składowych, w tym kosztów przypisywanych poszczególnym chorobom. „Traktując zatem chorobę - zdarzenie zdrowotne, lecz także jako zagadnienie gospodarcze, szczególnego znaczenia nabiera szacowanie pelnych ekonomicznych skutków, jakie ona niesie. Podczas gdy w krajach rozwiniętych badania takie są zaawansowane, w Polsce brak rzetelnych szacunków całkowitego (bezpośredniego, i pośredniego) obciążenia gospodarki kosztami chorób i niesprawności” ${ }^{1}$.

\section{Analiza kosztów choroby}

Analiza kosztów choroby ma na celu oszacowanie calkowitego kosztu choroby bądź stanu zdrowia dla społeczeństwa poprzez identyfikację, pomiar oraz wycenę kosztów bezpośrednich i pośrednich ${ }^{2}$.

Koszty bezpośrednie to wartość wszystkich dóbr i usług związanych ze zużyciem zasobów potrzebnych do zapewnienia kompleksowej opieki medycznej. Wyróżniamy koszty bezpośrednie medyczne i niemedyczne. Koszty bezpośrednie medyczne obejmują koszty zużycia zasobów lączących się z procesem leczenia i ponosi je bezpośrednio system ochrony zdrowia. Zaliczamy do nich m.in.: koszty leków i innych środków leczniczych, koszty monitorowania terapii, konsultacji medycznych, koszty badań laboratoryjnych, hospitalizacji, działań niepożądanych oraz amortyzacji sprzętu medycznego. Koszty bezpośrednie niemedyczne to wszystkie zasoby, które wspomagają „proces świadczenia usług medycznych przez sektor ochrony zdrowia” ${ }^{3}$. To inne koszty powstałe bezpośrednio w wyniku choroby lub jej leczenia, ale niebędące kosztami związanymi z terapią i procedurami medycznymi. Są to koszty transportu, specjalnej diety, adaptacji urządzeń w domu lub w miejscu pracy, które ułatwiają pacjentom petnienie funkcji zawodowych oraz społecznych. To także koszty, którymi zostaje obarczona rodzina chorego, przeznaczająca swój czas na opiekę nad osobą hospitalizowanąa ${ }^{4}$.

Koszty pośrednie natomiast to wartość utraconej produkcji z powodu nieobecności chorych w pracy, zmniejszenia wydajności oraz przedwczesnej umieralności ${ }^{5}$. Koszty pośrednie są rzadko uwzględniane w polskich analizach kosztów chorób. Różne sposoby kalkulacji kosztów utraconej produktywności wskazują na potrzebę wypracowania jednolitej oraz powszechnie akceptowanej metodyki ich szacowania ${ }^{6}$.

Na rycinie 1 przedstawiono oddziaływanie choroby na podmioty ekonomiczne oraz sytuację sektora finansów publicznych. Skutki choroby (1) dotykają osoby pracujące bezpośrednio lub pośrednio - gdy choruje członek rodziny lub gdy osoba pracująca staje się opiekunem osoby chorej. Konsekwencją choroby jest zmniejszenie zasobu pracy w gospodarce, którego dostarczają gospodarstwa domowe (2). Ze względu na zly stan zdrowia pracownicy nie są w stanie pracować lub pracują mniej wydajnie, co powoduje ograniczenie wytwarzania w przedsiębiorstwach, dla których praca jest równie ważnym jak kapitał czynnikiem produkcji (3). Spadek wielkości dochodów gospodarstw domowych (4), a co 


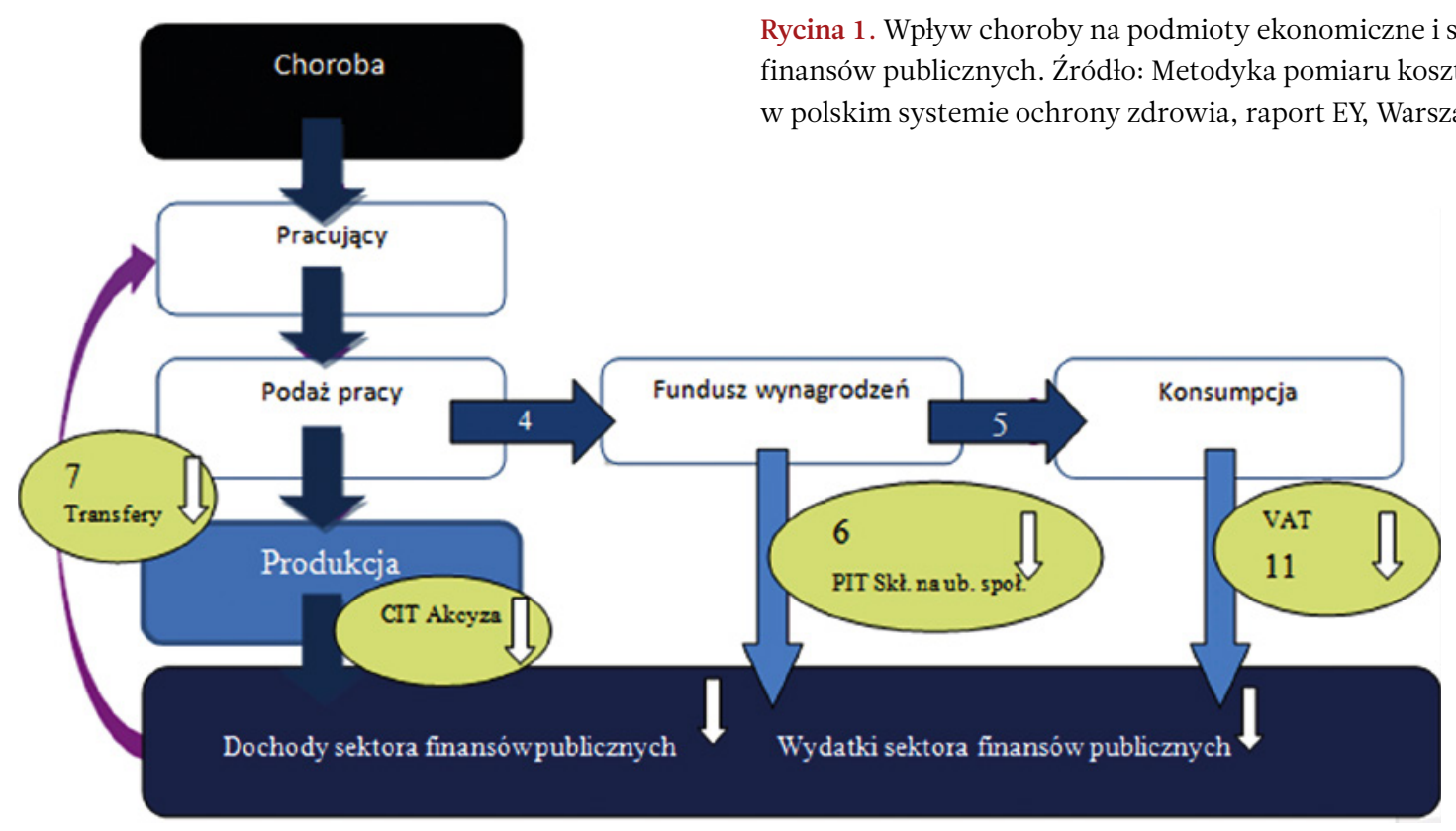

za tym idzie - obniżenie konsumpcji (5), to efekt zredukowania czasu pracy. Z kolei utrata zarobków, zmniejszenie poziomu konsumpcji przez gospodarstwa domowe oraz obniżenie produkcji przez przedsiębiorstwa sprawiają, że do budżetu odprowadzanych jest mniej podatków i składek (6) oraz zwiększają transfery wyplacane przez państwo na rzecz gospodarstw domowych (7). Konsekwencją tego jest pogorszenie kondycji sektora finansów publicznych $^{7,8}$.

Przedstawiona na rycinie 1 strata produkcji to ogólna definicja kosztów pośrednich przyjęta przez Światową Organizację Zdrowia.

Choroba powinna być rozpatrywana jako istotne zdarzenie gospodarcze. „W modelu (model Solow-Swan) opracowanym przez Dele i Anderson (2006) analizowano wpływ chorób przewlekłych (cukrzycy, chorób serca, udaru) na gospodarkę kraju, przede wszystkim wplyw na produkt krajowy brutto (PKB). Autorzy wykazali, że spadek zasobów siły roboczej w kraju jest zależny od absencji, poziomu niepetnosprawności, rent i wcześniejszych emerytur oraz skrócenia oczekiwanego czasu ży-

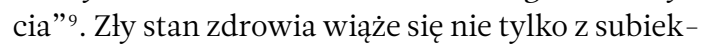
tywnym poczuciem niższej użyteczności u chorego, lecz także istotnie oddziałuje na czynniki ekonomiczne, takie jak: podaż pracy, wydajność w pracy, status ekonomiczny czy poziom edukacji. Na poziomie makroekonomicznym może się to przekładać na efektywność całego społeczeństwa, jakość i długość życia oraz pośrednio na wiek faktycznego zakończenia aktywności zawodowej.

Mając na uwadze powyższe, należy wskazać, że koszty pośrednie obejmują:

- Absenteizm - nieobecność w pracy z powodu złego stanu zdrowia. W przypadku nieobecności pracownika wielkość produkcji, którą mógłby wytworzyć, gdyby był zdrowy, jest zasobem utraconym z punktu widzenia gospodarki jako całości. Prezenteizm - obecność w pracy pomimo obniżonego samopoczucia, które jest konsekwencją złego stanu zdrowia. Pogorszenie samopoczucia przekłada się przede wszystkim na niższą efektywność pracownika w porównaniu z sytuacją, gdy jest on zdrowy. Prezenteizm uwzględnia także koszt obniżonej produktywności bezpośrednio po okresie choroby.

- Trwałą niezdolność do pracy lub zgon z powodu choroby - jest to ograniczenie produktywności. W tym modelu pacjent catkowicie rezygnuje $\mathrm{z}$ aktywności zawodowej, $\mathrm{w}$ przeciwieństwie do zwolnień chorobowych, w trakcie których osoba chora formalnie pozostaje pracownikiem, tyle że $\mathrm{w}$ danym okresie jest nieobecna w pracy.

- Opiekę nieformalną - opieka nad osobą chorą może być realizowana nieodplatnie przez rodzinę, co jest definiowane jako opieka nieformalna. Często odbywa się kosztem innych obowiązków i pracy zawodowej ${ }^{10}$.

Koszty choroby mogą być ocenione jako koszt całkowity zużytych zasobów, ponoszonych przez określone podmioty, lub szerzej - jako koszt catkowity systemu ochrony zdrowia (tabela 1). Dokładniej rzecz ujmując, jest to ustalenie finansowego obciążenia publicznego płatnika za świadczenia zdrowotne pacjenta, a co za tym idzie - sektora finansów publicznych oraz społeczeństwa. Analiza kosztów choroby koncentruje się tylko na kosztach - nie uwzględnia kwestii związanych z efektywnością leczenia ${ }^{11}$.

Ocena kosztów choroby może być przeprowadzana na podstawie rozpowszechnienia danego 
Tabela 1. Kategorie kosztów w zależności od przyjętej perspektywy.

Źródło: Orlewska E., Podstawy farmakoekonomiki, Oficyna Wydawnicza Unimed, Warszawa 1999, s. 40

\begin{tabular}{|c|c|c|c|c|}
\hline Pacjent & Świadczeniodawca & Narodowy Fundusz Zdrowia & Finanse publiczne & Spoteczeństwo \\
\hline $\begin{array}{l}\text { Koszty bezpośrednie, } \\
\text { w tym m.in.: } \\
\text { - opłaty z własnej kieszeni } \\
\text { - koszty transportu } \\
\text { - koszty opieki }\end{array}$ & $\begin{array}{l}\text { koszty bezpośrednie, } \\
\text { w tym m.in.: } \\
\text { - koszty hospitalizacji }\end{array}$ & $\begin{array}{l}\text { koszty bezpośrednie, w tym m.in.: } \\
\text { - koszty leków } \\
\text { - koszty podstawowej opieki zdrowotnej } \\
\text { - koszty ambulatoryjnej opieki zdrowotnej } \\
\text { - koszty leczenia szpitalnego } \\
\text { - koszty rehabilitacji i leczenia } \\
\text { uzdrowiskowego } \\
\text { - koszty badań diagnostycznych }\end{array}$ & $\begin{array}{l}\text { koszty bezpośrednie } \\
\text { i pośrednie, w tym m.in.: } \\
\text { - koszty leczenia } \\
\text { - świadczenia rentowe } \\
\text { - świadczenia chorobowe } \\
\text { - świadczenia rehabilitacyjne }\end{array}$ & $\begin{array}{l}\text { koszty bezpośrednie i pośrednie, } \\
\text { w tym m.in.: } \\
\text { - koszty hospitalizacji } \\
\text { - koszty leczenia ambulatoryjnego } \\
\text { - koszty leków } \\
\text { - koszty transportu } \\
\text { - utrata produkcyjności }\end{array}$ \\
\hline
\end{tabular}

schorzenia (prevalance-based analysis) lub na podstawie danych dotyczących zapadalności na określoną chorobę (incidence-based analysis). Najczęściej stosuje się podejście oparte na chorobowości (prevalence-based analysis), które umożliwia określenie całkowitego kosztu choroby. W tej metodzie uzyskuje się oszacowaną wartość kosztów rozpoznanych przypadków choroby w danym roku. Koszty składowe (bezpośrednie i pośrednie) ustala się w różny sposób ${ }^{12,13}$.

\section{Metody szacowania kosztów bezpośrednich i pośrednich}

Koszty bezpośrednie oblicza się za pomocą techniki kalkulacji kosztów „z góry do dołu” lub „z dołu do góry” bądź obydwu ${ }^{14}$. W pierwszej metodzie, tzw. makro lub od ogółu do szczegółu, całkowity koszt sektora ochrony zdrowia dzielony jest przez poszczególne jednostki chorobowe. Druga technika, znacznie częściej stosowana (mikro, od szczegółu do ogółu), polega na badaniu zużytych zasobów opieki zdrowotnej i społecznej oraz kosztów związanych z konkretnym schorzeniem, ponoszonych przez grupy pacjentów lub instytucje ochrony zdrowia. Kolejnym etapem jest grupowanie i sumowanie kosztów. W tabeli 2 przedstawiono kategorie zasobów, które są uwzględniane podczas obliczania kosztów metodą od szczegółu do ogółu, a także sposoby wyznaczania liczby i wartości w przypadku poszczególnych kosztów.

Do oszacowania kosztów pośrednich niezbędna jest wiedza m.in. na temat przeciętnych dziennych zarobków mężczyzn i kobiet w różnych grupach wiekowych, przeciętnej straty dni produkcyjnych w zależności od płci i wieku oraz długości okresu ich działalności zawodowej. Koszty pośrednie oblicza się z użyciem metody kapitału ludzkiego (najczęściej) lub metody kosztów frykcyjnych. Wybór metody zależy od rodzaju dostępnych danych ${ }^{15,16}$.

W pierwszym przypadku szacuje się wartość potencjalnie utraconej produktywności, która jest konsekwencją choroby. „Potencjalnie”, ponieważ w przypadku trwatego inwalidztwa lub przedwczesnego zgonu w określonym wieku jako koszty pośrednie liczona jest całkowita wartość utraconych zarobków do określonego wieku emerytalnego ${ }^{17}$. Nie bierze się tutaj pod uwagę, że w razie nieobecności pracownika praca może być wykonywana przez inną osobę bądź też w późniejszym czasie przez pracownika, który powrócił do zdrowia. Jest to dość skomplikowana metoda. Z kolei metoda kosztów frykcyjnych zakłada, że wartość utraconej w wyniku choroby produkcyjności zależy od tego, ile czasu potrzeba do odbudowania pierwotnego poziomu produktywności. „W przypadku krótkotrwałej nieobecności w pracy część obowiązków chorego pracownika może zostać przejęta przez

Tabela 2. Kategorie zasobów używane do szacowania kosztów metodami mikro.

Źródło: Morris S., Devlin N., Parkin D., Ekonomia w ochronie zdrowia, Oficyna a Wolters Kluwer business, Warszawa 2011, s. 356

\begin{tabular}{|c|c|c|}
\hline Rodzaj kosztu & Jednostka miary zasobu & Wartość zasobów: ceny, przypisane ceny lub jednostki kosztów \\
\hline \multicolumn{3}{|l|}{ Ustugi zdrowotne } \\
\hline Personel (według typów personelu) & czas & płace + dodatkowe koszty \\
\hline Materiały eksploatacyjne (np. jedzenie, strzykawki, lekarstwa) & ilość, liczba dawek & cena \\
\hline Leczenie szpitalne & liczba dni spędzonych w szpitalu & cena rynkowa \\
\hline \multicolumn{3}{|l|}{ Inne ustugi, w tym } \\
\hline Ustugi spoteczne i ambulatoryjne & kwota & cena \\
\hline \multicolumn{3}{|l|}{ Pacjenci, rodziny i opiekunowie } \\
\hline Czas & godziny & wskaźniki płac, przypisane im wartości \\
\hline Koszty pozostałe & kwota & cena \\
\hline Zmiana zarobków & czas & stawki płac \\
\hline
\end{tabular}


pozostałych, zaś mniej pilne obowiązki mogą zostać wypelnione przez pracownika po jego wyzdrowieniu lub czasami można całkowicie zaniechać ich wykonania. Przyjmuje się zatem założenie o niepelnym wykorzystaniu zasobu pracy w gospodarce" 18 .

\section{Podsumowanie}

Ocena kosztów bezpośrednich i pośrednich choroby uświadamia, jakie znaczenie ekonomiczne mają określone jednostki chorobowe, pomaga określić priorytety badawcze oraz identyfikuje chorych, którzy odnoszą największe korzyści z leczenia. Stanowi także punkt odniesienia, względem, którego szacowane będą $\mathrm{w}$ przyszłości korzyści wynikające z leczenia, wreszcie jest źródłem danych wykorzystywanych w kompleksowej analizie farmakoekonomicznej ${ }^{19}$.

Otrzymano: 2018.06.03 - Zaakceptowano: 2018.07.12

\section{Przypisy}

1. Ruszkowski J., Leśniowska J.: Rzeczywiste, ekonomiczne koszty choroby w Polsce. Polskie Stowarzyszenie Zarządzania Wiedzą 2010, 25.

2. Orlewska E.: Podstawy farmakoekonomiki, Oficyna Wydawnicza Unimed, Warszawa 1999

3. Czech M.: Farmakoekonomika - ekonomiczna ocena programów ochrony zdrowia, Oficyna Wydawnicza Politechniki Warszawskiej, Warszawa 2004.

4. Lis J., Hermanowski T, Czech M.: Koszty, jakość i wyniki w ochronie zdrowia, International Society For Pharmacoeconomics and Outcomes Research, Warszawa 2009.
5. Schultz A., Edington D.: Employee health and presenteeism: a systematic review, Journal of Occupational Rehabilitation, 2007, 17 (3): 547-579.

6. Hermanowski T.: Szacowanie kosztów społecznych choroby i wpływu stanu zdrowia na aktywność zawodową i wydajność pracy, ABC a Wolters Kluwer business, Warszawa 2003.

7. Metodyka pomiaru kosztów pośrednich w polskim systemie ochrony zdrowia, EY, Warszawa 2013.

8. Department of Health Systems Financing Health Systems and Services, WHO guide to identifying the economic consequences of disease and injury, Genewa 2009, http://www.who.int/choice/publications/d_economic_impact_guide.pdf.

9. Abegunde D., Stanciole A.: An estimation of the economic impact of chronic noncommunicable diseases in selected countries, WHO Department of Chronic Diseases and Health Promotion (CHP) (2006).

10. Metodyka pomiaru kosztów pośrednich w polskim systemie ochrony zdrowia, EY, Warszawa 2013.

11. Morris S., Devlin N., Parkin D.: Ekonomia w ochronie zdrowia, Oficyna a Wolters Kluwer business, Warszawa 2011.

12. Orlewska E., Nowakowska E.: Farmakoekonomika dla studentów i absolwentów Akademii Medycznych, Dział Wydawnictw Uczelnianych Akademii Medycznej im. Karola Marcinkowskiego w Poznaniu, Poznań 2004.

13. Rice D.P.: Estimating the cost of illness, American Journal of Public Health and the Nation's Health 1967, 57(3): 424-440.

14. Nojszewska E.; Racjonalizacja kosztów w ochronie zdrowia, Oficyna a Wolters Kluwer business, Warszawa 2012.

15. Glied S.: Estimating the indirect costs of illness: an assessmnet of foregone earnings approach, The American Journal of Public Health 1996, 86(12): 1723-1728.

16. Liljas B.: How to calculate indirect costs in economic evaluations, Pharmacoeconomics 1998, 13(1): 1-7.

17. Koopmanschap M., Burdorf A., Jacob K., Meerding W., Brouwer W., Severens H.: Measuring productivity changes in economic evaluation. Setting the research agenda, Pharmacoeconomics 2005, 23(1): $47-54$.

18. Koopmanschap M.A., Rutten, F.F.H., van Ineveld, B.M., van Roijen, L.: The friction cost method for measuring indirect costs of disease, Journal of Health Economics 1995, 14(2): 171-189.

19. Wrona W., Hermanowski T., Jakubczyk M., Golicki D., Czech, M., Niewada, M., Kolasa K.: Koszty utraconej produktywności w analizach farmakoekonomicznych. Część II. Badanie opinii w grupie ekspertów, Przegląd epidemiologiczny 2011, 65(1): 153-157. 